JURNAL PENDIDIKAN, p-ISSN 2715-095X, e-ISSN 2686-5041

Volume 30, No.3, Nopember 2021 (387-398)

Online: http://journal.univetbantara.ac.id/index.php/jp

\title{
Permainan Medikar Limai_Untuk Meningkatkan Penguatan Pendidikan Karakter (PPK) di SD Negeri Sukoharjo 04
}

\author{
Khosyiatun \\ Kepala SDN Sukoharjo 04, Sukoharjo, Email:Dra.khosyiatun@gmail.com/081393052590 \\ Received: Oktober 02, $2021 \quad$ Accepted: Oktober 08, $2021 \quad$ Online Published: Nopember 08, 2021
}

\begin{abstract}
Abstrak: Kondisi riil yang terjadi di SDN Sukoharjo 04 Kabupaten Sukoharjo sejak tahun pelajaran 2018/2019 dari hasil asesmen awal pelaksanaan PPK sudah mulai nampak di sekolah namun belum membudaya. Mencermati permasalahan yang timbul dapat dirumuskan masalah yaitu: 1) bagaimanakah meningkatkan PPKmelalui permainan Medikar Limai di SD Negeri Sukoharjo 04? dan 2) bagaimanakah hasil PPK melalui permainan Medikar Limai di SD Negeri Sukoharjo 04?. Best Practce ini bertujuan untuk mendeskripsikan langkah-langkah untuk meningkatkan PPK melalui permainan Medikar Limai di SD Negeri Sukoharjo 04 dan untuk mengetahui hasil PPK melalui permainan Medikar Limai di SD Negeri Sukoharjo 04.Strategi yang digunakan untuk mencari solusi pemecahan masalah dengan menggunakan permainan Medikar Limai. Langkah-langkah yang ditempuh melalui tiga tahapan antara lain tahap asesmen awal, tahap pelaksanaan,tahap evaluasi. Tindakan pada tahap pelaksanaan meliputi PPK berbasis kelas, Implementasi Nilai Utama PPK dan Aktivitas Peseerta didik saat Bermain Medikar Limai. Semua langkah tersebut telah disusun instrumen dan rubrik penilaian yang akan dinilai oleh penulis.Hasil yang dicapai implementasi PPK berbasis kelas dan implementasi 5 nilai utamaPPK telah menujukkan peningkatan hasil yang mulanya pelaksanaan PPK sudah mulai nampak di lingkungan sekolah menjadi pelaksanaan PPK sudah membudaya. Aktivitas peserta didik saat bermain Medikar Limai yang telah dilakukan menunjukkan hasil peserta didik mengalami perubahan perilaku yang tadinya mulai berkembang menjadi membudaya. Guru yang semula belum mengintegrasikan lima nilai utama ke dalam rencana pembelajaran kini sudah konsisten untuk mengintegrasikan nilai utama tersebut dalam skenario pembelajaran. Peserta didik yang awalnya belum nampak dalam penanaman lima nilai utama PPK juga telah menujukkan perubahan dengan pembiasaan yang membudaya dan juga terjadinya peningkatan hasil belajar.
\end{abstract}

Kata-kata Kunci: Medikar Limai, PPK, permainan

\section{Medikar Limai Game To Improve The Strengthening Of Character Education (PPK) In SD Negeri Sukoharjo 04}

\begin{abstract}
Khosyiatun
HeadmasterSDN Sukoharjo 04, Sukoharjo,Email:Dra.khosyiatun@gmail.com/081393052590

Abstract:The real conditions that have occurred at SDN Sukoharjo 04 Sukoharjo Regency since the 2018/2019 school year from the results of the initial assessment of the implementation of KDP have begun to appear in schools but have not become entrenched. Observing the problems that arise, problems can be formulated, namely: 1) how to improve KDP through the Medikar Limai game at SD Negeri Sukoharjo 04? and 2) how were the results of the PPK through the Medikar Limai game at SD Negeri Sukoharjo 04?. This Best Practice aims to describe the steps to improve KDP through the Medikar Limai game at SD Negeri Sukoharjo 04 and to find out the results of KDP through the Medikar Limai game at SD Negeri Sukoharjo 04. The strategy used to find solutions to problem solving using the Medikar Limai game. The steps taken through three stages are as follows: initial assessment stage; implementation stage; evaluation
\end{abstract}


stage. Actions at the implementation stage include class-based PPK, Implementation of KDP Main Values and Student Activities when Playing Medikar Limai. All these steps have developed an assessment instrument and rubric that will be assessed by the author. The results achieved by the implementation of classroom-based KDP and the implementation of the 5 main values of KDP have shown an increase in results from the beginning of the implementation of KDP that has begun to appear in the school environment to the implementation of KDP that has become entrenched. The activities of students while playing Medikar Limai that have been carried out show the results of students experiencing changes in behavior that had begun to develop into a culture. The impact of the implementation of KDP with Medikar Limai is very much felt. Teachers who initially have not integrated the five main values into the lesson plan are now consistent in integrating these core values into learning scenarios. Learners who initially did not appear in the cultivation of the five main values of KDP have also shown changes with entrenched habituation and also an increase in learning outcomes

Keywords: Medikar Limai, PPK, game

\section{Pendahuluan}

Gerakan Penguatan Pendidikan Karakter(PPK) menempatkan karakter sebagai poros pendidikan nasional yang meletakan makna dan nilai karakter sebagai jiwa atau generator utama penyelenggaraan pendidikan nasional. PPK hadir menjadisolusi untuk menyiapkan generasi emas 2045 yang mempunyai kecakapan abad 21 melaluipenempatan karakter laksana ruh pendidikan di Indonesia. Hubungannya dengan perkembangan intelektualitas PPK berperan dalam pembentukan generasi muda yang tangguh, cerdas dan berkarakter. Berdasarkan Peraturan Presiden Nomor 87 Tahun 2017 tentang penguatan pendidikan karakter bahwa penyelenggaraan penguatan tersebut pada satuan pendidikan formal saat ini juga menempatkan nilai karakter sebagai demensi terdalam pendidikan yang harus dibiasakan dan dibudayakan dalam berbagai aktivitas pendidikan. Lima nilai-nilai esensial karakter yang perlu dikembangkan serta dibudayakan sebagai pioritas gerakan PPK yaitu religius, nasionalis, mandiri, gotong-royong dan integritas. Nilai-nilai tersebut dipilih berdasarkan pancasila, Gerakan Nasional Revolusi Mental (GNRM), kebutuhan nasional juga kearifan lokal bangsa Indonesia. Kementrian Pendidikan dan Kebudayaan (2017:23) menekankan bahwa PPK di sekolah dalam mempersiapkan daya saing, sekolah diharapkan bisa mengembangkan budaya belajar yang menumbuhkan keterampilan abad 21 yakni (berpikir kritis. kreatif, komunikasi, kolabrasi serta literasi multimedia), baik pada pada pembelajaran juga pada pengembangan budaya sekolah daan kolaborasi dengan masyarakat. Lima nilai esensial PPK (Penguatan Pendidikan Karakter) yang dikembangkan dan dibudayakan di sekolah bukan nilai yang berdiri sendiri melainkan nilai yang berhubungan satu dengan yang lain, yang berkembang secara dinamis dan membentuk keutuhan pribadi. Model pelaksanaan PPK pada sekolah yang mampu membangun karakter kepribadian yang kuat, kokoh, dan mantap dalam diri peserta didik, sekolah harus mengintegrasikan lima nilai esensial PPK kedalam kegiatan belajar mengajar, pembiasaan dalam kehidupan seharihari di sekolah, kemudian terintegrasi ke dalam kegiatan ekstrakurikuler, kokurikuler serta intrakurikuler. Kondisi riil yang terjadi di SDN Sukoharjo 04 Kabupaten Sukoharjo sejak tahun pelajaran 2018/2019 dari hasil asesmen awal pelaksanaan PPK sudah mulai terlihat dilingkungan sekolah tetapi belum membudaya. Faktot dari guru terutama dalam mengintegrasikan nilai-nilai utama PPK dalam desain RPP Kurikulum 13 yang meliputi kegiatan pendahuluan, inti dan penutup, baru 25\% PPK dengan tingkatan sudah mulai terlihat di sekolah. Rendahnya motivasi guru untuk berprestasi yang ditunjukan kenerjanya 
masih stagnan biasa-biasa saja, jika diberi informasi untuk mengikuti pengembangan diri, misalnya mengikuti diklat belum termotivasi ikut kegiatan diklat dan inovasi guru dalam mendesain proses pembelajaran khususnya.Peran guru dalam mengembangkan 5 nilai Penguatan Pendidikan Karakter (PPK) yang meliputi religius, nasionalis, mandiri, gotong royong dan integritas baru pada tingkatan sudah mulai terlihat di lingkungan sekolah dan belum membudaya. Motivasi guru untuk berprestasi juga masih rendah yang ditunjukan kenerjanya masih stagnan biasa-biasa saja, jika diberi informasi untuk mengikuti pengembangan diri, misalnya mengikuti diklat baru sebagian yang ikut dengan alasan sebagian besar merasa belum ada gunanya karena sebagian besar masih berstatus Guru Tidak Tetap (GTT). Sekolah mempunyai 10 karyawan yang 6 guru kelas yang 5 berstatus Guru GTT yang ASN hanya 1.

Faktor dari peserta didik masih banyak perilaku negatif peserta didik saat mengikuti proses pembelajaran yaitu masih berada di luar kelas padahal bel sudah berbunyi, peserta didik ada yang belum mengerjakan PR, peserta didik ada yang menyontek, peserta didik belum siap saat guru masuk, peserta didik terlalu lama di kamar mandi, serta masih dikantin padahal jam pelajaran sudah dimulai, dan masih dijumpai peserta didik ada yang sering membuat ulah. Faktor lain, sumber pembiayaan juga masih terbatas masih tergantung dari dana pemerintah yaitu BOS (Bantuan Operasional Sekolah). Ketersedian sarpras belum belum memenuhi standar minimal yang berbasis multi media. Sekolah sampai tahun pelajaran 2020/2021 baru mempunyai 3 laptop dan 2 Liquid Crystal Display (LCD). Perhatian dan dukungan dari wali murid dan komite sekolah belum berjalan secara optimal. Kepedulian warga sekolah terhadap taman dan tanaman bunga serta penataan dilingkungan sekolah masih kurang. Tanaman banyak yang kering dan tumbuh rerumputan karena jarang disiangi dan disirami, sehingga perlu adanya penanaman nilai nilai karakter.

Faktor pendukung untuk mengimplementasikan terutama pada lima nilai esensial PPK antara lain memiliki guru-guru yang mempunyai kualifikasi akademi yang tepatpada bidangnya studi yang diampu dan memiliki kemampuan guru dalam menggunakan teknologi informasi dan teknologi komunikasi (TIK) sebagai media dan sumber belajar, serta memiliki semangat gotong-royong kekeluargaan yang tinggi, kedisiplinan masuk kerja, dan jiwa pengabdian yang tinggi. Penguatan Pendidikan Karakter yang diterapkan pada peserta didik dalam pelaksanaannya tidak semudah membalikkan telapak tangan tetapi membutuhkan proses dengan jangka waktu yang panjang untuk menanamkan nilai-nilai karakter yang diharapkan. Hal ini dibutuhkan kreatifitas dan inovasi dari guru menggunakan berbagai model dan media yang menarik. Salah satu alternatif untuk mengatasi permasalahan tersebut adalah melalui Permainan Medikar Limai (Media Karakter Lima Nilai).

Medikar Limai ini penulis desain, dengan memodifikasi permainan "SEMAI" (Sembilan Nilai) antikorupsi yang merupakan salah satu permainan yang dikenalkan oleh Gerakan "Saya Perempuan Anti Korupsi" (SPAK) dan KPK adalah jenis permainan yang ditujukan sebagai bagian dari gerakan untuk mencoba menanamkan nilai-nilai anti korupsi untuk peserta didik. Sembilan nilai ini diantaranya, kejujuran, kepedulian, kegigihan, keadilan, tanggungjawab, kerjasama, sederhana, keberanian dan kedisiplinan. Badriyah (2018:7) dalam pengabdianya di SD Negeri Percobaan 1 Kota Malang menjelaskan pengalaman yang diperoleh bahwa melalui permainan semai (Permainan Sembilan Nilai) berdampak positif yaitu terbentuk peserta didik terdapat perubahan perilaku yang terlihat dalam kemandirian dalam Jum'at Bersih, penghematan untuk konsumsi di sekolah,peningkatan amal yang dilaksanakan dalam Jum'at Berbagi, kedisiplinan yang 
terlihat dalam penurunan jumlah peserta didik yang terlambat, serta kepercayaan diri yang terlihat dalam kegiatan ulangan.

Medikar Limai (Media Karakter Lima Nilai) merupakan sebuah media yang diaplikasikan dengan pendekatan bermain seraya belajar yang melibatkan keaktifan peserta didik mencoba memahami 5 (Lima nilai) PPK yang diharapkan akan menumbuhkan sikap atau perilaku yang mencerminkan karakter tepat dengan PPK. Medikar Limai didesain dilengkapi dengan buku panduan yang telah dibuat. Permainan ini mencakup papan permainan (beberan), kartu putih berisi sebuah situasi, dan kartu merah berisi satu pertanyaan. Kartu-kartu memuat sikap keseharian yang baik yang sebaiknya dimiliki dan ditanamkan dalam diri peserta didik sejak dini. Melalui permainan medikar limai yang berbasis pembiasaan ke dalam 5 nilai utama penguatan pendidikan karakter diharapkan nilai-nilai tersebut mudah dicerna, dipahami dan ditiru sehingga internalisasi nilai, dilakukan secara alamiah dan menyenangkan dalam kehidupan sehari-hari. Karakter diibaratkan sebuah titian antara keterampilan dan ilmu pengetahuan. Pengetahuan tanpa didasari kepribadian yang benar akan berujung menyesatkan dan keterampilan tanpa didasari kesadaran diri akan menghancurkan (Asmani, 2011:27). Salah satu tujuan pendidikan nasional adalah pendidikan karakter. Pendidikan karakter merupakan sesuatu yang dilakukan oleh guru untuk mengugkan karakter peserta didik. Menurut Agus Prasetyo dan Emusti Rivasintha (dalam Kurniawan 2019:30) yang mengungkapkan bahwa pendidikan karakter dianggap suatu langkah penanaman nilai karakter peserta didik yang mencakup kemauan atau kesadaran, dan pengetahuan, dan tindakan untuk mengimplementasikan nilai tersebut. Desy Nurlaida Khotimah. (2018) dalam penelitiannya menjelaskan bahwa Tujuan program Penguatan Pendidikan Karakter adalah menanamkan nilai-nilai pembentukan karakter bangsa ke peserta didik secara masif dan efektif melalui lembaga pendidikan dengan prioritas nilai-nilai tertentu yang akan menjadi fokus pembelajaran, pemahaman, pengertian, dan praktik, sehingga pendidikan karakter sungguh dapat mengubah perilaku, cara berpikir, dan cara bertindak seluruh bangsa Indonesia menjadi lebih baik dan berintegritas, senada dengan penelitian tersebut. Senada dengan penelitan tersebut Ima Wahyu Putri Utami (2018) dalam penelitiannya menjelaskan salah satu tujuan dari Penguatan Pendidikan Karakter (PPK) yaitu menanamkan nilai religious, dengan menanamkan nilai religius diharapkan mampu mengubah perilaku dan cara berpikir dan bertindak.

Penyelenggaraan pendidikan karakter di sekolah harus berpedoman pada nilai-nilai karakter dasar manusia yang kemudian akan dikembangkan menjadi nilai yang lebih tepat sesuai kondisi, kebutuhan dan lingkungan (Asmani, 2011:33). Mengutip Suyanto (dalam Kurniawan 2019:33) bahwa pendidikan karakter diimplementasikan sejak usia dini atau sering disebut sebagai usia emas (golden age) yang terbukti dapat menentukan anak dalam mengembangkan potensinya. Berdasarkan paparan tersebut dapat ditegaskan bahwa pendidikan karakter sangatlah penting untuk ditanamkan dan untuk mengembangkannya diperlukan adanya penguatan pendidikan karakter. Pengutaan Pendidikan Karakter adalah program pendidikan pada satuan pendidikan untuk menguatkan karakter peserta didik melalui penyatuab olah pikir, olah hati, olah rasa dan olah raga dengan keterlibatan kerjasama antara satuan pendidikan, keluarga dan masyarakat (Permendikbud No. 20 tahun 2018). Gerakan PPK mempunyai lima nilai utama yang saling berkaitan yang mencerminkan nilai-nilai Pancasila. PPK dapat dicapai melalui aktivitas berbasis kelas, sekolah, serta masyarakat. 
Lima nilai-nilai utama PPK yaitu sebagai berikut. Pertama religius, nilai religius merupakan nilai yang mencerminkan iman kepada Tuhan Yang Maha Esa yang terwujud dalam sikap taat ajaran sesuai agama dan kepercayaan yang dianut dan toleransi bergama. Nilai karakter ini memuat tiga dimensi interaksi yajni hubungan individu dengan Tuhan, individu dengan sesama, dan individu dengan alam. Karakter tersebutditampilkan dalam sikap mencintai dan mengjaga keutuhan sebagai ciptaan Tuhan Yang Maha Esa. Nilai-nilai yang terkandung antara lain menghormati perbedaan agama dan kepercayaan, berpendirian teguh, kolaborasi antar pemeluk agama, persahabatan, ketulusan, toleransi, cinta damai, juga tidak memaksakan kehendak.

Kedua nasionalis, nilai karakter nasionalisialah cara berpikir, bertindak dan bersikap mencerminkan kesetiaan, penghargaan tinggi, jugaperhatian yang lebih terhadap bahasa, fisik, sosial dan budaya, ekonomi, serta politik bangsa yang menjadikan bangsa dan negara di atas kepentingan sendiri. Nilai-nilai nasionalis yang haru dikembangkan meliputi rela berkorban, cinta tanah air, taat hukum, menjaga lingkungan, melestarikan keragaman budaya, dan menjaga kekayaan bangsa, apresiasi budaya sendiri.

Ketiga, nilai utama mandiri merupakan perwujudan sikap tidak bergantung pada orang lain dan senantiasa menggunakan tenaga, pikiran, dan waktu untuk mewujudkan mimpi dan cita-cita. Nilai-nilai mandiri yang harus dikembangkan meliputi etos kerja, tangguh, daya juang, tahan banting, professional, kreatif, berani serta menjadi orang yang belajar sepanjang hayat.

Keempat gotong royong, nilai karakter gotong royong merupakan perwujudan tindakan menghargai sikap kerjasama dan berkolaborasidemi memecahkan suatu persoalan, menjalin komunikasi dan memberikan bantuan pada orang yang membutuhkan. Nilai-nilai gotong-royong yang haru dikembangkan meliputi kerjasama, berkomitmen atas keputusan bersama, musyawarah untuk mufakat, kerja sama, saling menolong, solidaritas yang tinggi, tidak diskriminasi, anti kekerasam dan sikap sukarela.

Kelima integritas,nilai integritas merupakan nilai yang menjadi dasar perilaku seseorang sebagai pihak yang dapat dipercaya dalam perkataan, perbuatan dan pekerjaan, dan juga memiliki komitmen kesetiaan pada nilai kemanusiaan dan moral. Nilai-nilai integritas yang harus dikembangkan meliputi kejujuran, komitmen moral, anti korupsi, keadilan, tanggung jawab, jujur, keteladanan, tanggungjawab, dam menghargai martabat individu.

Tujuan akhir dalam pembelajaran karakter adalah membentuk bangsa yang kokoh, berahlak mulia, kompetitif, berorientasi IPTEK dan dijiwai iman dan taqwa kepada Tuhan Yang Maha Esa berpedoman Pancasila. Mengutip Lickona (dalam Hamzah 2019:26) menjelaskan bahwa perkembangan karakter biasanya terjadi dalam komunitas, seperti sekolah yang dapat mendorong hubungan yang saling menghormati sehingga peserta didik dan warga sekolah bekerjasama untuk mencapai tujuan. Usaha untuk mengoptimalkan karakter peserta didik tergantung bergantung pada kemampuan pihak terkaitantara lain sekolah, guru, peserta didik, orang tua, dan masyarakat sekitar. Hal ini telah dibuktikan oleh Hary, Ramdani dan Rahmah dalam penelitihan yang dilakukan di 3 sekolah unggulan di kota Bandung yaitu SMP Tunas Unggul, SMAN 8 dan SMPN 44, hasil implementasi pendidikan karakter berjalan sangat efektif karena didukung oleh berbagai kebijakan, aksi nyata, dan konsistensi serta keseriusan sekolah dalam mendukung program tersebut. Sekolah mempunyai tanggung jawab yang besar terhadap penguatan pendidikan karakter, secara formal karena pada sekolah dasar peserta didik minimal berada di sekolah kurang lebih 6 sampai 7 jam/hari. Hamzah (2019:27) menjelaskan sekolah formal merupakan salah 
satu tempat yang diharapkan untuk pembentukan karakter peserta didik diperlukan strategi yaitu: (1) guru sebagai pengasuh, teladan dan pembimbing, (2) membangun komunitas moral di dalam kelas, (3) menegakkan disiplin moral, (4) menciptakan lingkungan kelas yang demokratis, dan (5) mengajarkan nilai-nilai moral melalui kurikulum (Hamzah (2019:27). Penanaman nilai karakter memerlukan tahapa-tahapan yang memerlukan proses dan waktu yang panjang agar nilai-nilai karakter benar-benar dapat terinternalisasi atau mendarah daging dalam diri peserta didik. Salirawati (2018:178) menjelaskan tahapantahapan proses penanaman karakter sebagai berikut:1)di awal penanaman karakter Belum Terlihat (BT) perubahan karakter, 2)Secara perlahan-lahan akan Mulai Terlihat (MT), dan seiring berjalannya waktu di dalam jiwa peserta didik tersebut berproses sehingga nilainya akan Menjadi Berkembang (MB), akhirnya akan berujung pada keberhasilan guru menanamkan karakter hingga Membudaya (M).

Implementasi lima nilai utama ini dalam kegiatan pembelajaran dalam bentuk RPP kurikulum 13 diintegrasikan pada kegiatan pendahuluan, inti, dan penutup. Indikator keberhasilan pelaksanaan PPK berbasis kelas dijelaskan oleh Tim PPK Kementerian Pendidikan dan Kebudayaan (2017:10) yaitu: 1) guru mengintegrasikan nilai utama PPK dalam rencana pelaksanaan pembelajaran (RPP), 2) guru mengembangkan langkah pembelajaran yang dapat memperkuat nilai karakter, 3) guru menghubungkan materi pembelajaran dengan kehidupan sehari-hari, dan 4) kapasitas guru dikembangkan secara berkelanjutan. Permainan atau bermain bagi peserta didik adalah wahana atau sarana belajar mendewasakan diri dengan cara yang menyenangkan. Ungguh (2016:205) menjelaskan metode bermain adalah metode yang menggunakan permainan tertentu sebagai sarana pembelajaran siswa. Jenis permainan yang biasa dilakukan oleh peserta didik antara lain permainan sensorimotor,yaitu permainan yang menggunakan semua indera, permainan simbolis, yaitu pemainan yang biasa dilakukan peserta didik dengan berpura pura, atau permainan konstruktif, yaitu permainan yang menggabungkan sensorimotor dan simbolis, permainan sosial yaitu permainan yang dilakukan di mana peserta didik berinteraksi sosial dengan temanmainnya, dan juga permainan kompetisi yang melibatkan aturan aturan dalam bermain.

Lima manfaat riil dari metode bermain yang dijelaskan oleh Ungguh (2017:205-206) yakni pertama manfaat motorik yangberkaitan dengan nilai positifgame yang terjadi pada fisik dengan unsur-unsur kesehatan, keterampilan, ketangkasan, juta kemampuan fisik. Manfaat kedua ialah afeksi, manfaat yang berkaitan dengan berkembangnya psikologis peserta didik dengan unsur yang meliputi naluri/insting, emosi, sifat, karakter, serta watak maupun kepribadian seseorang. Ketiga, manfaat kognitif manfaat permainan untuk berkembangnya kecerdasan anak yang berkaitan dengan kemampuan imajinasi, penyusunan nalar dan logika, maupun pengetahuan yang sistematik. Keempat, manfaat yang hampir sama dengan afeksi, tetapi berisi unsur-unsur kesucian, keluhuran budi pekerti, serta nilai positif. Manfaat ini merupakan kolaborasi nilai positif dari afektif dan kognisi. Sedangkan manfaat kelima iaah manfaat keseimbangan tumbuh kembang anak yang berfungsi melatih serta mengembangkan kepaduan antara nilai positif dan negatif dari suatu permainan.

Taris (2016:102) menjelaskan agar peserta didik lebih aktif untuk belajar diperlukan salah satu media pembelajaran dalam bentuk permainan, karena permainan menyenangkan untuk dilakukan. Penggunaan media pembelajaran inovatif dapat memberikan pengaruh positif bagi peserta didik untuk meningkatkan kualitas belajarnya sangatlah diperlukan. Permainan edukatif merupakan media pembelajaran yang membuat anak bermain seraya 
belajar sehingga anak tidak merasa terbebani dalam penguasaan materi, karena mereka merasa sedang melakukangame yang merupakan permainan yang mereka sukai sehari-hari, sehingga materi dapat teresap dengan kemauan anak sendiri. Berkaitan dengan implementasi lima nilai utama PPK diperlukan sebuah permainan edukatif yang membuat peserta didik bermain sambil belajar sehingga merasa tidak terbebani dan merasa senang karena bermain-main dengan game yang merupakan permainan yang mereka sukai seharihari. Penggunaan media pembelajaran inovatif bisaberdampak positif bagi peserta didik untuk meningkatkan kualitas belajarnya sangatlah diperlukan. Sementara yang terjadi saat ini sebagian guru ada yang belum memanfaatkan media pembelajaran secara optimal. Sundayana (2015:32) menjelaskan media ialah segala sesuatu yang dapat menyalurkan informasi dari sumber informasi kepada penerima informasi sedangkan dihubungkan dengan pembelajaran diartikan media pembelajaran adalah segala sesuatu yang dapat digunakan untuk menyalurkan informasi dari guru ke peserta didik sehingga dapat menstimulasi pikiran, perasaan perhatian dan minat peserta didik dan pada akhirnya dapat menjadikan peserta didik melakukan dengan baik dalam kegiatan belajar. Sejalan pendapat (Hamzah, 2019: 194) menjelaskan media pembelajaran merupakan satu dari sekian komponen strategi penyampaian yang berisikan muatan pesan kepada peserta didik berupa orang, alat, maupun bahan.

Keberadaan media ini diharapkan dapat menstimulasi kegiatan belajar seperti mendorong untuk berdiskusi, mendorong munculnya peluang debat antar peserta didik, dan keterampilan berpikir peserta didik. Bahan media belajar berfungsi sebagai psychological tools yang berperan untuk menjembatani kesenjangan antara muatan kognitif dan muatan belajar peserta didik. Media yang digunakan dalam pembelajaran berperan sebagai perantara untuk menciptakan pengalaman belajar yang bermakna.

Medikar Limai penulis desain, dengan memodifikasi permainan semai yang diluncurkan pertama kali, bersamaan dengan peringatan setahun program SPAK pada 21 April 2015 di Jakarta. Melaui permainan semai KPK mencoba menanamkan nilai-nilai anti korupsi kepada peserta didik. Sembilan nilai ini diantaranya, kejujuran, kepedulian, kegigihan, keadilan, tanggungjawab, kerjasama, sederhana, keberanian dan kedisiplinan. Hal yang serupa hasil desain media pembelajaran yang dibuat oleh Izzah (2019) yang diberi nama "Semai Games" ini sangat memudahkan Santri-santri untuk lebih cepat memahami nilai anti korupsi dalam penerapanikap sehari-hari di rumah ataupun disekolah. Perubahan perilaku nampak dalam kemandirian pada kegiatan sabtu bersih, penghematan dalam aspek konsumsi di sekolah, peningkatan angka amal yang dilaksanakan dalam Jum'at shadaqoh, kedisiplinan yang nampak dalam penurunan jumlah Santri yang terlambat, serta kepercayaan diri yang terlihat dalam kegiatan ulangan dan perlombaan antar sekolah.

Medikar Limai (Media Karakter Lima Nilai) merupakan sebuah media yang digunakan dengan pendekatan bermain sambil belajar yang melibatkan keaktifan peserta didik mencoba memahami lima nilai utama yang diharapkan akan menumbuhkan sikap atau perilaku yang mencerminkan karakter sesuai dengan PPK. Lima nilai utama karakter yang dikembangkan yaitu: relegius, nasionalis, mandiri, gotong royong dan integritas.

Permainan Medikar Limai menunjukkan bahwa dalam permainan limai terdapat banyak nilai-nilai berkarakter positif yang termuat di dalamnya. Kartu-kartu memuat perilaku yang baik yang harus dimiliki dan ditanamkan dalam diri peserta didik yang tercakup dalam Penguatan Pendidikan Karakter (PPK) dan penerapannya dalam kehidupan sehari-hari. Lima Nilai yang terkandung dalam permainan ini yaitu religius, nasionalis mandiri, gotong royong, dan integritas. Dengan permainan yang berbasis pembiasaan pada lima nilai utama 
penguatan pendidikan karakter, nilai-nilai tersebut mudah dicerna, dipahami dan ditiru sehingga internalisasi nilai, dilakukan secara alamiah dan menyenangkan. Medikar Limai dilakukan dengan menggunakan buku panduan yang telah dibuat. Permainan ini terdiri dari papan permainan (beberan), kartu putih berisi sebuah situasi, dan kartu merah berisi satu pertanyaan.

Langkah-langkah dan cara bermain Medikar Limai melalui 3 langkah yaitu, langkah pendahuluan, pelaksanaan permainan dan penutup. Sebelum permainan Medikar Limai fasilitator memimpin doa dilanjutkan mengucapkan salam PPK dan tepuk PPK mempersilahkan mengenalkan kelompoknya di lanjutkan yel-yel kelompok. Langkah inti permainan ini meliputi: 1) Permainan dimainkan oleh dua orang atau kelompok dan dipandu seorang fasilitator (jumlah anggota kelompok bebas), 2) fasilitator menjelakan cara dan aturan permainan kepada peserta dan pastikan mereka memahaminya, 3) perwakilan kelompok melakukan suit untuk menentukan siapa peserta yang memulai terlebih dahulu, 4) pemain yang mendapat giliran pertama harus mengambil satu kartu putih, membaca dengan seksama situasi yang digambarkan di situ, lalu menentukan apakah situasi tersebut termasuk kelompok religius, nasionalis, mandiri, gotong- royong, dan integritas, 5) pemain meletakan kartu putih tersebut pada salah satu kotak di papan permainan (Beberan) sesuai kelompoknya, 6) pemain lawan diharuskanmenilaidengan didasari alasan yang tepat, apakah jawaban tersebut benar atau salah, 7)fasilitator memimpin jalannya diskusi dan memberikan putusan, bila jawaban tersebut salah, peserta diharuskan mengambil kartu merah lalu menjawab pertanyaan atau malakukan perintah yang tercakup di dalamnya. Begitu seterusnya bergiliran, 8) peserta atau kelompok yang menang, ialahkelompo yang terbanyak dalam menempatkan kartu putih dan paling sedikit mendapat kartu merah. Pada kegiatan penutup terdiri dari: 1) memberikan penguatan dan memberikan hadiah kelompok yang menang, 2) melakukan yel-yel kelompok, 3) fasilitator dan peserta melakukan salam PPK dan tepuk PPK secara bersama-sama dan 4)permainan diakhiri dengan berdoa dipimpin oleh kelompok yang menang.

Permainan yang berbasis pembiasaan pada situasi lima nilai utama PPK, diharapkan nilai-nilai tersebut bisa dengan mudah dicerna, dimengertiserta ditiru. Sehingga implementasinilai, dilakukan secara alami dan menyenangkan. Perlu diyakini internalisasi nilai karakter mungkin manfaatnya tidak cepat dirasakan, tetapi dengan permainan ini akan berdampak positif terhadap peserta didik pribadi di masa depan. Berpijak dari permasalahan di atas penulis terinspirasi untuk mendesain alat permainan Medikar Limai (Media Karakter Lima Nilai) yang digunakan untuk mengimplementasikan lima nilai-nilai utama PPK. Best practice ini akan mengupas "Permainan Medikar Limai untuk Meningkatkan Penguatan Pendidikan Karakter (PPK) di SD Negeri Sukoharjo 04”.

Dari latar belakang masalah di atas maka dapat dirumuskan permasalahan ini sebagai berikut: "Bagaimanakah meningkatkan Penguatan Pendidikan Karakter (PPK) melalui permainan Medikar Limai di SD Negeri Sukoharjo 04? Bagaimanakah hasil Penguatan Pendidikan Karakter (PPK) melalui permainan Medikar Limai di SD Negeri Sukoharjo 04)?. Tujuan dari diadakan penelitian ini agar dapat menjawab permasalahan yang telah dirumuskan yaitu Mengacu pada rumusan masalah yang telah dirumuskan di atas bertujuan sebagai berikut. Untuk mendeskripsikan langkah-langkah untuk meningkatkan Penguatan Pendidikan Karakter (PPK) melalui permainanMedikar Limai di SD Negeri Sukoharjo 04. Untuk mengetahui hasil Penguatan Pendidikan Karakter (PPK) melalui permainan Medikar Limai di SD Negeri Sukoharjo 04.

\section{Metode Penelitian}


Langkah-langkah yang ditempuh di SD Negeri Sukoharjo 04 Kabupaten Sukoharjo sejak tahun pelajaran 2018/2019, 2019/2020 dan 2020/2021, tentang implementasi nilainilai utama Penguatan Pendidikan Karakter (PPK). Adapun langkah-langkah yang ditempuh sebagai berikut: 1) tahap asesmen awal; 2) tahap pelaksanaan ; 3) tahap evaluasi.Kegiatan atau tindakan yang dilakukan untuk mengimplementasikan nilai-nilai utama PPK yaitu religius, nasionalis, gotong-royong, mandiri, dan integritas sebagai berikut. Kegiatan sosialisasi program PPK yang dilaksanakan dengan kepala sekolah sebagai narasumber dan komite sekolah serta perwakilan orang tua siswa sebagai peserta, Implementasi PPK Berbasis Kelas. Implementasi Nilai-Nilai Utama PPK. Kegiatan yang dilakukan untuk meningkatkan Penguatan Pendidikan Karakter (PPK) dalam bentuk permainan Medikar Limai pada tahun 2020/2021 yaitu berdoa bersama mengawali permainan, Bersama-sama melalukan salam dan tepuk PPK, Peserta menyanyikan yel-yel kelompok, Fasilitator menjelaskan aturan permainan, Peserta meletakkan kartu putih sesuai dengan nilai yang tepat, Pemain bergantian membacakan kartu putih, Peserta mengambil kartu merah karena salah meletakkan kartu putih, Permainan diakhiri dengan salam dan tepuk PPK, Pelaksanaan Medikar Limai dengan Mahasiswa PPL pada tahun 2019.

Kegiatan yang dilakukan dalam evaluasi Penguatan Pendidikan Karakter (PPK) antara lain Menidaklanjuti hasil monotoring PPK, Diskusi evaluasi pelaksanaan permainan, Hasil kegiatan pengembangan secara berkelanjutan yang dibuat dalam bentuk artikel yang dipublikasikan di media masaa antara lainArtikel populer yg di publikasikan Senin, 12 November 2018, Artikel populer yang dipublikasikan Senin, 25 Maret 2019, Artikel populer yang dipublikasikan Rabu, 12 Desember 2018, Artikel Populer yang dipublikasikan Minggu 20 Januari 2019.

\section{Hasil Penelitian}

Berdasarakan data hasil asesmen awal tabel di atas pada tahun 2018/2019 pelaksanaan PPK sudah mulai nampak di lingkungan sekolah tetapi belum sempurna dan perlu perbaikan. Pada tahun 2019/2020 asesemen awal menujukkan bahwa pelaksanaan PPK di sekolah sudah jadi kebiasaan. Setelah dilakukannya evaluasi tiap tahun pelajaran, pada asesmen awal tahun 2020/2021 menunjukkan bahwa pelaksanaan PPK sudah membudaya di sekolah. PPK Berbasis Kelas yang telah dijalankan selama 3 tahun pelajaran terakhir juga telah menujukkan peningkatan dari tahun ke tahun. Penialain berbasis kelas ini bertujuan untuk menilai pelaksanaan PPK yang berfokus pada guru. Sistem penilaian PPK berbasis kelas ini sama dengan asesmen awal. Pada tahun 2018/2019 PPK berbasis kelas sudah mulai terlihat dilingkungan sekolah cukup baik hanya saja belum semua guru mengintegrasikan nilai-nilai utama PPK dalam desai RPP yang digunakan. Pelatihanpelatihan yang ada juga jarang diikuti oleh guru-guru karena merasa belum berguna untuk saat itu. Pada tahun pelajaran 2019/2020 PPK berbasis kelas sudah baik dan telah menjadi kebiasaan yang dilakukan oleh guru dalam setiap pembelajarannya. RPP sudah teritegrasi meski belum seluruh guru mengembangkan skenario pembelajaran yang memuat nilai karakter. Pada tahun 2020/2021 pelaksanaan PPK berbasis kelas pelaksanaan PPK sudah membudaya. Inti dari pelaksanaan PPK ini adalah keberhasilan implementasi 5 nilai utama yang meliputi religius, nasionalisme, mandiri, gotong royong dan integritas. Implementasi lima nilai ini telah didukung dengan adanya Medikar Limai yang membantu siswa untuk lebih mengerti dan paham mengenai nilai-nilai yang penting dalam pembentukan karakter. 
Data hasil implementasi lima nilai yang telah dilaksanakan disajikan dalam tabel sebagai berikut:

Tabel 1 Data Hasil Implementasi Nilai Utama PPK

\begin{tabular}{|c|c|c|c|c|c|}
\hline \multirow[b]{2}{*}{ No } & \multirow[b]{2}{*}{ Implementasi Nilai-Nilai Utama } & \multicolumn{3}{|c|}{ Tahun Ajaran } & \multirow{2}{*}{$\begin{array}{l}\text { Rata- } \\
\text { rata }\end{array}$} \\
\hline & & \multirow{2}{*}{$\begin{array}{l}2018 / \\
2019\end{array}$} & \multirow{2}{*}{$\begin{array}{l}2019 / \\
2020\end{array}$} & \multirow{2}{*}{$\begin{array}{l}2020 / \\
2021\end{array}$} & \\
\hline & mempunyai & & & & \\
\hline 1. & $\begin{array}{l}\text { pengembangan religiusitas peserta didik } \\
\text { sesuai dengan agama dan } \\
\text { kepercayaannya }\end{array}$ & 3 & 3 & 4 & 2,6 \\
\hline 2. & $\begin{array}{l}\text { Sekolah meningkatkan kegiatan-kegiatan } \\
\text { yang mengembangkan semangat } \\
\text { nasionalisme }\end{array}$ & 2 & 3 & 4 & 3,3 \\
\hline 3. & $\begin{array}{l}\text { Sekolah meningkatkan kegiatan yang } \\
\text { menumbuhkan kemandirian }\end{array}$ & 2 & 3 & 4 & 3,3 \\
\hline 4. & $\begin{array}{l}\text { Sekolah mengembangkan kegiatan yang } \\
\text { menampilkan semangat gotong-royong }\end{array}$ & 3 & 4 & 4 & 3 \\
\hline 5. & $\begin{array}{l}\text { Sekolah menetapkan peraturan yang } \\
\text { menumbuhkan nilai integritas }\end{array}$ & 2 & 3 & 4 & 3 \\
\hline \multicolumn{2}{|c|}{ Jumlah } & 12 & 16 & 20 & \\
\hline \multicolumn{2}{|c|}{ Skor Akhir } & 2,4 & 3,2 & 4 & \\
\hline \multicolumn{2}{|c|}{ Predikat } & $\mathrm{C}$ & $\mathrm{B}$ & A & \\
\hline
\end{tabular}

Berdasarkan tabel di atas dapat diketahui bahwa pada awal sebelum penerapan permainan Medikar Limai implementasi nilai utama masih dalam pelaksanaan PPK sudah mulai nampak di lingkungan sekolah. Setelah dilakukannya Medikar Limai pada tahun 2019/2020 dan tahun 2020/2021, penerapan PPK semakin menunjukkan peningkatan dan menunjukkan pelaksanaan PPK di sekolah sudah jadi kebiasaan. Perbaikan-perbaikan yang diperlukan telah dilaksanakan dan PPK berjalan dengan lancar dan bisa dikatakan bahwa pelaksanaan PPK sudah membudaya.

Selain melakukan penilaian pada guru dan sekolah mengenai pelaksanaan PPK, pada saat permainan Medikar Limai juga dilakukan penilaian aktivitas pesesta didik dari awal sampai akhir permainan. Data hasil implementasi permainan Medikar Limai pada tahun 2019/2020 dan 2020/2021 sebagai berikut

Tabel 2 Data Hasil Penilaian Aktivitas Peserta Didik Saat Permainan Medikar Limai

$\begin{array}{ccc}\text { Kelas } & & \text { Tahun Pelajaran } \\ \text { I } & 2019 / 2020 & 2020 / 2021 \\ \text { II } & 3,00 & 3,67 \\ \text { III } & 3,00 & 3,67 \\ \text { IV } & 3,00 & 3,78 \\ \text { V } & 3,33 & 3,78 \\ \text { VI } & 3,33 & 3,67 \\ \text { Kategori } & 3,44 & 3,89 \\ & \text { Mulai Berkembang } & \text { ( A ) } \\ \end{array}$


Keterangan:

$1-1,99$ (D) : Belum Terlihat

$2-2,99(\mathrm{C})$ : Mulai Terlihat

3,0 - 3,5 (B) : Mulai Berkembang

3,6 - 4,0 (A) : Membudaya

Berdasarkan tabel hasil rekapitulasi aktivitas peserta didik saat berlangsungnya permainan Medikar Limai pada tahun 2019/2020 menunjukkan bahwa lima nilai utama dalam aktivitas peserta didik sudah mulai berkembang. Seiring dilakukannya pembiasaan implementasi nilai PPK disekolah, pada tahun 2020/2021, lima nilai utama peserta didik dalam aktivitas bermain Medikar Limai telah menunjukkan hasil yang bagus dan sudah membudaya.

\section{Pembahasan}

Hasil yang dicapai implementasi PPK berbasis kelas dan implementasi 5 nilai utamaPPK berdasarkan tabel di atas telah menujukkan peningkatan hasil yang mulanya pelaksanaan PPK sudah mulai nampak di lingkungan sekolah menjadi pelaksanaan PPK sudah membudaya.Aktivitas peserta didik saat bermain Medikar Limai yang telah dilakukan menunjukkan hasil peserta didik mengalami perubahan perilaku yang tadinya mulai berkembang menjadi membudaya. Penelitian juga telah dilakukan oleh Desy Nurlaida Khotimah (2018) yang menyatakan bahwa penerapan PPK berpengaruh pada perilaku siswa. Ima Wahyu Putri Utami. (2018) juga melakukan penelitian dengan hasil bahwa dengan peneraoan PPK melalui pembiasaan dapat mewujudkan perilaku toleransi.

Dampak dari pelaksanaan Medikar Limai di SD Negeri Sukoharjo 04 adalah peningkatan prestasi siswa, salah satunya pada kelas 6 tahun pelajaran 2018/2019 rata-rata ujian sekolah adalah 82,29 telah meningkat menjadi 83,47 pada tahun pelajaran 2019/2020. Hal ini dikarenakan optimalnya pembelajaran di kelas dengan implementasi lima nilai PPK sehingga menjadikan kelas yang kondusif dan pembelajaran menjadi bermakna

\section{Simpulan dan Saran}

Berdasarkan hasil implementasi dan pembahasan yang dilakukan oleh penulis dapat disimpulkan bahwa Media Karakter Lima Nilai (Medikar Limai) dapat meningkatkan Penguatan Pendidikan Karakter (PPK) di SD Negeri Sukoharjo 04. Hal ini ditunjukkan melalui pencapaian indikator keberhasilan yang dipaparkan yaitu Pelaksanaan implementasi PPK berbasis kelas dan implementasi nilai-nilai utama PPK di sekolah mengalami peningkatan yang mulanya pelaksanaan PPK sudah mulai nampak di lingkungan sekolah menjadi pelaksanaan PPK sudah membudaya. Hasil yang diperoleh dari bermain Medikar Limai lima nilai utama PPK adalah adanya perubahan perilaku pesrerta didik yang tadinya mulai berkembang menjadi membudaya.

Berdasarkan hasil implementasi yang dilakukan, penulis mengajukan beberapa rekomendasi yang dapat dijadikan pertimbangan rujukan dalam menerapkan Pendidikan Penguatan Karakter di sekolah Permainan Media Karakter Lima Nilai (Medikar Limai) dapat memberikan pengalaman positif dan menjadi pengembangan bagi seluruh pihak sekolah dalam penanaman nilai-nilai karakter utama.Permainan Media Karakter Lima Nilai (Medikar Limai) dapat memberikan alternatif solusi dalam implementasi Pendidikan Penguatan Karakter (PPK) di sekolah serta dapat dijadikan pertimbangan untuk 
mengembangkan manajemen serupa.Kreativitas dan inovasi guru perlu ditingkatkan dalam rangka meningkatkan kualitas pendidikan di sekolah.

\section{Daftar Rujukan}

Asmani, J. Ma'mur. 2011. Buku Panduan Internalisasi Pendidikan Karakter di Sekolah. Yogyakarta: DIVA Press

Badriyah, Nurul. 2018. Pemantapan Dan Penanaman Nilai Dan Sikap Anti Korupsi Pada Anak-Anak Dengan Permainan yang Menyenangkan (Permainan Semai Dari “Gerakan Spak”-Kpk). Jurnal Jurnal Studi Kasus Inovasi Ekonomi. 02 (01): 7-18. http://ejournal.umm.ac.id/index.php/skie

Desy Nurlaida Khotimah. (2018). Implementasi Program Penguatan Pendidikan Karakter (PPK) Melalui Kegiatan $5 s$ Di Sekolah Dasar. Inopendas Jurnal Ilmiah Kependidikan

Hamzah, Amir. 2019. Etos Kerja Guru Era Industri 4.0. Malang: CV. Literasi Nusantara Abadi.

Hary R, Ramdani Z, dan Rahmah B. 2020. Best Ptactice Pendidikan Karakter pada Sekolah Unggulan di Bandung. Indonesian Journal of Education. 02 (01): 61-71. https://doi.org/10.26499/ijea.v3il.61

Ima Wahyu Putri Utami. (2018). Analisis Penerapan PPK Melalui Praktik Ibadah Kelas Rendah SD Muhammadiyah 9 Kota Malang. Jurnal JPSD Vol. 5 No. 1

Izzah, Lailatul. 2019. Menumbuhkan Nilai-Nilai Anti Korupsi Pada Anak untuk Membentuk Karakter Melalui "Semai Games" diMDTA Rabithatul Ulum $\begin{array}{llllll}\text { Pekanbaru. Jurnal Psikologi. } & 2 & \text { (2) } & \text { : } & \text { 84-95. }\end{array}$ http://ojsbimtek.univrab.ac.id/index.php/psi/article/view/748

Kementian Pendidikan dan Kebudayaan, 2017. Panduan Penilaian Penguatan Pendidikan Karakter.Jakarta:TIM PPK Kemendikbud

Kurniawan, Syamsul. 2019. Pendidikan Karakter : Konsepsi \& Implementasinya Secara Terpadu di Lingkungan Keluarga, Sekolah, Perguruan Tinggi, \& Masyarakat. Yogyakarta: Ar-Ruzz Media

Peraturan Presiden No. 87 Tahun 2017 tentang Penguatan Pendidikan Karakter.https://peraturan.bpk.go.id/

Salirawati, Das. 2018. Smart Teaching:Solusi Menjadi Guru Profesional. Jakarta: Bumi Aksara

Sundayana,H dan Rostina.2015.Media dan Alat Peraga Dalam Pembelajaran Matematika.Bandung:CV.Alfabeta

Taris, L. dan Mantasiah R. 2016. Implementasi Media Pembelajaran Anti KorupsiBerbasis Gender untuk Menanamkan Nilai-NilaiKejujuran di SD. Indonesian Journal of Education Studies. 19(2): 100-107. https://doi.org/10.26858/ijes.v19i2.3592

Ungguh, J.S. 2016. 45 Model Pembelajaran Spektakuler: Buku Pegangan Teknis Pembelajaran di Sekolah. Yogyakarta. Ar-Ruzz Media 